\title{
COMMENT
}

\section{LONG-TERM BIAS AND DIRECTOR PRIMACY}

\author{
Stephen M. Bainbridge*
}

In an important recent contribution to the short-termism debate, Professors Michal Barzuza and Eric Talley challenge what they call an "emerging consensus in certain legal, business, and scholarly communities . . . that corporate managers are pressured unduly into chasing short-term gains at the expense of superior long-term prospects." See Michal Barzuza \& Eric Talley, Long-Term Bias, 2020 COLUM. BUS. L. REV. 104. Instead, Barzuza and Talley contend that "corporate managers often fall prey to long-term bias-excessive optimism about their own long-term projects."

This article is an invited comment on Barzuza and Talley's article. Subject to various quibbles raised herein, I broadly concur with Barzuza and Talley's argument that corporate directors and officers can be biased towards long-term projects and, accordingly, may reject short-term projects offering higher returns.

But what law reforms follow logically from their conclusion, if any? With respect to judicial review, I want to differ with Barzuza and Talley on three points. First, I believe Barzuza and Talley overstate the risk of judicial intervention. Second, they fail adequately to distinguish between directors and managers, even though that distinction is central to the application of Delaware law. Third, I believe their analysis implies that judges should retain the deference to director decisionmaking inherent in doctrines such as the business judgment rule and intermediate review.

* William D. Warren Distinguished Professor of Law, UCLA School of Law. 385 Charles E Young Drive East, Los Angeles, CA 90095. bainbridge@law.ucla.edu. Thanks to Jill Fisch for very helpful comments. 
With respect to encouraging shareholder activism, I argue that the responsibility for policing managerial hyperopia (or myopia, for that matter) should be assigned to the board of directors, not the shareholders. Heterogenous shareholders lack the proper incentives and knowledge to properly police management.

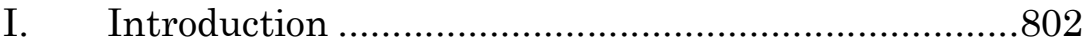

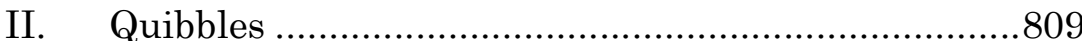

A. So Many Biases ................................................8 810

B. Overconfidence or Misperception? ....................812

C. The Case Studies ...........................................814

III. The Judicial Role ............................................... 818

A. Is it Really Just a "Matter of Time"?.................819

B. Directors Direct, and that Matters ....................820

C. The Judges Are Not Business Experts...............822

IV. Activist Shareholders to the Rescue? ........................824

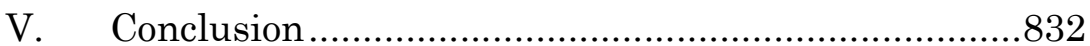

\section{INTRODUCTION}

Elite opinion holds as a virtual article of faith that corporations should be managed for the long term. Former Delaware Chief Justice Leo Strine argued "that the generation of durable wealth for its stockholders through fundamentally sound economic activity, such as the sale of useful products and services, is the primary goal of the forprofit corporation," laying emphasis on the idea of durablei.e., sustained long-term-growth. 1 Former Delaware Chancellor William Allen, one of the most respected corporate law jurists ever, likewise argued that "the proper orientation of corporation law is the protection of long-term value of

1 Leo E. Strine, Jr., One Fundamental Corporate Governance Question We Face: Can Corporations Be Managed for the Long Term Unless Their Powerful Electorates Also Act and Think Long Term?, 66 Bus. LAW. 1, 2 (2010). 
capital committed indefinitely to the firm."2 Delaware Vice Chancellor Laster opined that "the directors [must] act prudently, loyally, and in good faith to maximize the value of the corporation over the long-term for the benefit of" the corporation's shareholders. ${ }^{3}$ The Business Roundtable's latest statement on corporate purpose argued that corporations have responsibilities to all of their stakeholders, which include-but are not limited to—-creating "long-term value for shareholders."4

Conversely, elite opinion holds that managers are myopic-i.e., biased in favor of pursuing short-term gains-to the detriment of the corporation's long-term health and that of society at large. 5 Famed corporate lawyer Martin Lipton argued that "in order to create short-term action in the stock, you do things that are contrary to long-term investment." 6

2 William T. Allen, Ambiguity in Corporation Law, 22 DEL. J. CoRP. L. 894, 896-97 (1997).

3 Frederick Hsu Living Tr. v. ODN Holding Corp., No. 12108-VCL, 2017 WL 1437308, at *18 (Del. Ch. Apr. 14, 2017), as corrected, (Apr. 24, 2017). See also Musicland Holding Corp. v. Best Buy Co. (In re Musicland Holding Corp.), 424 B.R. 95, 101 (Bankr. S.D.N.Y. 2010) (holding that, even when a corporation is insolvent, "the directors and officers must still "exercise judgment in an informed, good faith effort to maximize the corporation's long-term wealth creating capacity."' (quoting Credit Lyonnais Bank Nederland v. Pathe Commc'ns Corp., No. 12150, 1991 WL 277613, at *34 (Del. Ch. Dec. 30, 1991))).

4 Press Release, Bus. Roundtable, Business Roundtable Redefines the Purpose of a Corporation to Promote 'An Economy That Serves All Americans' (Aug. 19, 2019), https://www.businessroundtable.org/businessroundtable-redefines-the-purpose-of-a-corporation-to-promote-an-economythat-serves-all-americans [https://perma.cc/7FCE-XJ5U].

5 See Henry T.C. Hu, Risk, Time, and Fiduciary Principles in Corporate Investment, 38 UCLA L. REV. 277, 308 (1990) ("Conventional wisdom holds that first, American corporate managers are myopic and debilitatingly riskaverse when it comes to research, machinery, and other productive investments.").

6 Jessica C. Pearlman, Interview with Marty Lipton, 75 Bus. LAW. 1709, 1718 (2020); see also James J. Park, Do the Securities Laws Promote ShortTermism?, 10 U.C. IRvine L. REV. 991, 993 (2020) ("Over the last several years, some of the most prominent representatives of Corporate America have argued that the pressure of mandatory quarterly disclosure creates incentives for public corporations to focus on meeting the short-term 
Prominent management guru Peter Drucker likewise complained of outside pressures leading managers to focus on short-term results. ${ }^{7}$ Former Delaware Supreme Court Justice Jack Jacobs contended that pressure on corporate managers to emphasize short-term profits has put the United States "on the brink of losing [its] premier position," as the largest global economy, "if it has not already."

This consensus has real-world consequences. To be sure, the Delaware Supreme Court has indicated that "directors, generally, are obliged to chart a course for a corporation which is in its best interests without regard to a fixed investment horizon."9 Yet, it is generally understood that corporate directors may put the interests of corporate stakeholders ahead of the short-term interests of shareholders, for example, as long as doing so contributes to long-term shareholder

expectations of the market rather than developing businesses that prosper over the long-term and make positive contributions to society."); see also Jesse M. Fried, The Uneasy Case for Favoring Long-Term Shareholders, 124 YALE L.J. 1554, 1558 (2015) (defining short-termism as "taking steps that boost the short-term stock price but reduce the economic value created by the firm over the long term").

7 See Peter F. Drucker, Editorial, A Crisis of Capitalism, Wall ST. J., Sept. 30, 1986, at A32 (contending that various external forces pressure corporate managers to emphasize short-term results at the expense of sustainable long-term gains).

8 Jack B. Jacobs, "Patient Capital": Can Delaware Corporate Law Help Revive It?, 68 WASH. \& LEE L. REV. 1645, 1649 (2011). See also K.J. Martijn Cremers, Saura Masconale \& Simone M. Sepe, Commitment and Entrenchment in Corporate Governance, 110 Nw. U. L. REV. 727, 749 (2016) (" $[\mathrm{M}]$ yopia models suggested that an excessive focus on stock market results, combined with imperfectly informative market prices, could induce managers to privilege short-term stock price gains over long-term cash flows."); James Cameron Spindler, Vicarious Liability for Managerial Myopia, 46 J. LEGAL STUD. 161, 167 (2017) ("The assumption of managerial myopia is common in the literature on securities fraud: it is presumed that managers are not in it for the long term and may maximize short-term stock price at the expense of long-term stock price and performance." (citations and footnote omitted)).

9 Paramount Commc'ns, Inc. v. Time Inc., 571 A.2d 1140, 1150 (Del. 1989). 
gains.10 In a more recent development, President Trump asked the SEC to consider abandoning the longstanding requirement of quarterly financial disclosure so as to relieve corporate managers of pressures to emphasize the short term, a position shared by a number of prominent lawyers and business leaders. ${ }^{11}$

Into this debate come Professors Michal Barzuza and Eric Talley with their article, Long-Term Bias, which argues not only that corporate managers can be biased in favor of the long term, but also that a focus on the long term may be just as detrimental as the more widely condemned short-term bias. 12

Barzuza and Talley's argument rests on one of the systematic biases to which behavioral economics has demonstrated decisionmakers are subject: the overconfidence

10 PRINCIPLES OF CoRP. GOVERnANCE: ANALYSIS AND RECOMMENDATIONS $\S 2.01$ cmt. f (AM. L. INST. 1994) ("Short-term profits may properly be subordinated to recognition that responsible maintenance of these interdependencies is likely to contribute to long-term corporate profit and shareholder gain.").

11 See Park, supra note 6, at 993-94 (describing Trump's request and the SEC's response). Professor Park notes support for eliminating or reducing quarterly disclosure among commentators, lawyers, and business leaders:

Martin Lipton, the prominent corporate lawyer, is a longtime critic of short-termism and proposed eliminating quarterly disclosure in 2015. In 2018, Jamie Dimon, the CEO of J.P. Morgan, and the legendary investor Warren Buffett proposed that companies no longer issue guidance about their earnings. Periodically, commentators have observed that the focus of markets on quarterly earnings results in short-termism.

Id. at 993 n.3 (citations omitted). A 2014 survey of pension fund investors "found that most favored semiannual or annual over quarterly reporting, partly because less-frequent reports appear to lower the temptation for corporate executives to play games with earnings targets." Jason Zweig, The End of Quarterly Reporting? Not Much to Cheer About, WALl ST. J. (Aug. 17, 2018, 5:08 PM), https://www.wsj.com/articles/the-end-of-quarterlyreporting-not-much-to-cheer-about-1534540127 (on file with the Columbia Business Law Review).

12 See generally Michal Barzuza \& Eric Talley, Long-Term Bias, 2020 Colum. Bus. L. REV. 104. 
bias. 13 Decisionmakers subject to overconfidence bias believe "that good things are more likely than average to happen to [them] and bad things are less likely than average to happen to [them]."14 To be sure, some decision makers really are smarter than others, such that good things do happen to them more often than to the average decision maker, but "all the children in Lake Wobegon cannot really be above average." 15

Barzuza and Talley offer three case studies of long-term bias-i.e., a preference for a long-term project over a shortterm option offering superior returns 16 -impacting decisions by corporate executives. 17 In each case, a CEO remained committed to a long-term plan despite mounting evidence that the returns on that project were likely inferior to short-term alternatives.18 All three CEOs exhibited overconfidence, which led them to overestimate their likelihoods of success and thus to miscalculate the value of their preferred projects relative to the alternatives. 19

Finally, Barzuza and Talley draw a number of implications from their analysis. First, they contrast the potential interplay in the capital markets of managerial long-term biases with short-term biases on the part of activist shareholders. 20 Then, they examine the implications of their analysis for three categories of business operations: "business

13 See id. at 135-39 (discussing the possibility that corporate managers are subject to the overconfidence bias).

14 Russell B. Korobkin \& Thomas S. Ulen, Law and Behavioral Science: Removing the Rationality Assumption from Law and Economics, 88 CALIF. L. REV. 1051, 1091 (2000).

15 Id.

16 See Barzuza \& Talley, supra note 12, at 135 tbl.1 (defining a longterm bias as "[a] preference for a long-term investment over a superior short-term investment/return”).

17 See id. at 155-72 (discussing the case studies).

18 See id. at 113 (arguing that "managerial overconfidence about longterm investments appears to have thrived" in each of the case studies).

19 See id. at 155-72 (discussing the case studies).

20 See id. at 173-75 (discussing interacting biases in capital markets). 
investment, investor payout, and firm governance."21 They also discuss the legal implications of their analysis. 22

One of the most impressive aspects of Barzuza and Talley's article is that it scrupulously avoids over-claiming. Indeed, to their credit, Barzuza and Talley never claim that the shortterm story is false.23 Instead, they make the more conservative and plausible argument that the debate is incomplete, because it fails to account for the possibility that management also may be subject to a long-term bias, which prompts them "to favor inferior long-term projects over shortterm alternatives that have superior returns." 24 Consequently, Barzuza and Talley do not deny that management is subject to pressures for short-term performance, although they argue that such pressures may be beneficial by counteracting management's long-term biases. 25

Barzuza and Talley are certainly correct that a long-term focus is not always optimal. At the very least, one must take into account discount rates. ${ }^{26}$ Accordingly, assuming a ten percent discount rate, a rational actor should prefer my offer of 91 cents today to my promise to pay $\$ 1$ in a year. 27 Behavioral economics, however, teaches that everyone-

21 Id. at 175.

22 Id. at 181.

23 See id. at 173 (acknowledging that "our framework and argument do not dismiss the possibility that short-term biases exist and are durable in capital markets"); see also id. at 120 (acknowledging that they "do not aspire to displace or refute the prevailing narrative about the dangers of shortterm bias").

24 Id. at $112,120$.

25 Id. at $116-17$.

26 See Amicus Curiae Brief of the Nat'l Ass'n of Chapter Thirteen Trs. Supporting Petitioners, Till v. SCS Credit Corp., 541 U.S. 456 (2004) (No. 02-1016) ("Present value is based upon the common sense notion that a dollar paid to you one year from now is less valuable to you than the dollar paid to you today.").

27 The present value of a dollar to be received in one year is 91 cents (rounded up) assuming a ten percent discount rate. See Roger D. Blair \& Christine A. Piette, Coupons and Settlements in Antitrust Class Actions, ANTITRUST, Fall 2005, at 33 n.15 ("The present value of a dollar to be received one year from now at an interest rate of 10 percent is $\$ 1.00 / 1.10=$ $\$ 0.909 . ”$. 
including corporate managers-is subject to biases that cause systemic departures from rationality. Indeed, the proposition that corporate managers can be subject to the overconfidence bias is neither new nor surprising. 28 To the contrary, as Barzuza and Talley explain, a number of studies and experiments confirm the phenomenon. 29

In addition, Barzuza and Talley are doubtless correct that managers often exhibit a bias towards the long term, rather than the short term assumed by conventional wisdom. As Bhagat and Hubbard explain, for example, there is a considerable body of "empirical evidence in the finance research consistent with managers and investors focusing on long-term shareholder value." 30 Likewise, other

28 See, e.g., Donald C. Langevoort, Organized Illusions: A Behavioral Theory of Why Corporations Mislead Stock Market Investors (and Cause Other Social Harms), 146 U. PA. L. REV. 101, 139-42 (1997) (discussing how the overconfidence bias can impact corporate decision makers); Susanna Kim Ripken, Predictions, Projections, and Precautions: Conveying Cautionary Warnings in Corporate Forward-Looking Statements, 2005 U. ILL. L. REV. 929, 959 (2005) ("For corporate managers, this overconfidence bias can lead not only to self-serving beliefs about their managerial skills, but also to an overestimation of their knowledge and of the validity of their judgments.").

29 See Barzuza \& Talley, supra note 12, at 136-39 (discussing the empirical evidence).

30 Sanjai Bhagat \& Glenn Hubbard, Should the Modern Corporation Maximize Shareholder Value? 7 (Am. Enter. Inst. Econ. Persps. No. 2020-08, 2020), https://www.aei.org/wpcontent/uploads/2020/09/Should-the-Modern-Corporation-MaximizeShareholder-Value.pdf (on file with the Columbia Business Law Review). They further explain that:

$[\mathrm{M}]$ ore than 80 percent of the initial public offerings (IPOs) in the United States have negative earnings during the 12 months before the IPO. Yet, the market value of these companies at the time of the IPO is often in the hundreds of millions of dollars - indeed for some, in the billions.

Investors in these IPOs and managers of these companies have to be thinking of something other than losses in valuing these companies. Investors and managers in these companies expect the company's earnings (cash flows) will grow over time, turn positive, and keep growing. The present value of these future earnings extending a decade 
commentators have contested the proposition that a shortterm focus is pervasive and inherently undesirable. 31

Barzuza and Talley thus have built their analytical framework on a solid foundation. Accordingly, I am concerned mainly with the implications that Barzuza and Talley draw from their analysis. Having said that, however, I open in Part II by offering some minor quibbles with their analysis. None of these quibbles invalidate it, but they may help flesh it out. In Part III, I turn to the implications of their analysis for judicial review of corporate decisions. Finally, in Part IV, I differ sharply with their recommendations regarding shareholder powers.

Both Parts III and IV ask similar questions. Are judges or shareholders better equipped than directors to distinguish among unbiased managers-both those suffering from shortterm bias and those suffering from long-term bias? And are judges or shareholders better equipped than directors to intervene when managers suffer from either short-term or long-term bias? My answer to both is a definitive "no."

\section{QUIBBLES}

Although I am in broad agreement with both Barzuza and Talley's thesis and their supporting arguments, a few qualifications are in order. First, I suggest that we do not know whether managers are more often subject to short- or long-term biases. Second, I suggest an alternative-albeit perhaps a complementary rather than competingexplanation for the management behavior Barzuza and Talley analyze. Third, I question their interpretation of the chosen case studies.

and longer, justifies the IPO valuation of hundreds of millions of dollars, or billions.

Id. (citation omitted).

31 See, e.g., C.L. Marston \& B.M. Craven, A Survey of Corporate Perceptions of Short-Termism Among Analysts and Fund Managers, 4 EUR. J. FIN. 233, 234 (1998) (stating that a number of commentators contend that short-termism is "of lesser importance than its supporters claim"). 


\section{A. So Many Biases}

Although there is good reason to suspect that managers can be biased in favor of long-term investments, 32 there are equally powerful countervailing stories suggesting that management can exhibit a bias towards the short term. The first such story points out that managers have strong incentives to focus on a time horizon defined by the anticipated lengths of their careers, which are relatively short compared to the lives of their corporations and the preferred time horizon of long-term investors. ${ }^{33}$ Managers logically should prefer short-term payoffs in order to boost their nearterm job prospects. This is so because short-term investment projects more quickly reveal their results and thus are better able to "dispel uncertainty about [the managers'] value on the job market." 34 In contrast, "shareholders have a longer horizon associated with the infinite life of the company." 35 And because shareholders can diversify away firm-specific risk, they are less exposed to risk than managers. ${ }^{36}$ As a result, risk-averse managers will tend to refrain from uncertain long-term projects even though shareholders might prefer such projects. ${ }^{37}$

32 See supra notes 28-31 and accompanying text (reviewing relevant studies).

33 See David I. Walker, The Challenge of Improving the Long-Term Focus of Executive Pay, 51 B.C. L. REV. 435, 441 (2010) ("[M] anagers might have a shorter investment horizon than shareholders because they expect to retire or leave the company in the near term and hence are not motivated to pursue long-term goals.").

34 Basma Sellami Mezghanni, Ownership Structure, Board of Directors and R\&D Investments: Evidence from France, 5 CORP. OWNERSHIP \& CONTROL 250, 250 (2008).

35 Id.

36 See Iman Anabtawi, Note, Toward a Definition of Insider Trading, 41 STAN. L. REV. 377, 387-88 (1989) ("The assumption that managers are more risk averse than investors is realistic because managers cannot diversify the impact of company profits on their portfolios as easily as can shareholders.").

37 See Mezghanni, supra note 34, at 250 (comparing the incentives of managers and shareholders). 
The alternative story makes the opposite assumption about the typical investor's preferred time horizon. Almost three decades ago, Wachtell Lipton partner Steven Rosenblum argued that investors "systematically overemphasize current information and immediate performance, and thus excessively discount future performance." 38 In their turn, he argued, "managers develop a systematic bias against long-term investments because [such investments] depress short-term share prices." 39

We continue to see this story advanced in the debate, as illustrated by the much more recent controversy over whether quarterly disclosure promotes short-termism.40 As with Barzuza and Talley's long-term bias story, this version of the short-term bias story rests on behavioral economics. As Russell Korobkin explains:

[I]f shareholders exhibit an endowment effect, this might affect the way that they evaluate the performance of their managers, thus causing rational managers to choose to act in a way that is cognizant of the effect. The pure loss aversion explanation of the endowment effect posits that losses are more painful than equivalent gains. This suggests managers might strive to avoid losses during every reporting period, even when doing so might mean making decisions that reduce the long-term profit potential of the firm. Managers might also continue to pursue existing projects after they have proven undesirable rather than terminating them and recognizing an apparent loss in the current reporting period, especially if shareholders can evaluate the project's outcome when it ends but not while it is ongoing. The endowment effect thus might counsel for establishing longer periods of time between corporate accounting periods, although this would need to be balanced against the

38 Steven A. Rosenblum, Proxy Reform, Takeovers, and Corporate Control: The Need for a New Orientation, 17 J. CoRP. L. 185, 205 (1991) (referring to an academic literature Rosenblum finds credible).

39 Id.

40 See supra text accompanying note 11 (describing President Trump's request that the SEC reconsider quarterly disclosure). 
costs of less immediate oversight of agents' activities. 41

My point is not that Barzuza and Talley's long-term bias story is wrong; it is only that their article has not given us any reason to think that managerial hyperopia is either more common or more problematic than managerial myopia. This is not to deny that the paper serves a useful purpose. They are quite correct that the debate needs to acknowledge and take into account the possibility of managerial hyperopia and the risk that it will not always be benign. Having said that, however, the difficulty in determining which bias is at work in any given situation leads me, in the Parts that follow, to draw rather different conclusions about the appropriate policy recommendations than those drawn by Barzuza and Talley.

\section{B. Overconfidence or Misperception?}

As we have seen, the overconfidence bias drives Barzuza and Talley's analysis. ${ }^{42}$ I suspect that something else is going on or, at least, is also contributing to managerial hyperopia. A number of commentators have argued that managers perceive the market as rewarding short-term performance-whether or not the market actually does so-and therefore will be biased towards producing short-term results. 43 Accordingly,

41 Russell Korobkin, The Endowment Effect and Legal Analysis, $97 \mathrm{Nw.}$ U. L. REV. 1227, 1281-82 (2003) (footnotes omitted).

42 See supra note 13 and accompanying text (discussing Barzuza and Talley's analytical framework).

43 See Andrea Bowdren, Contextualising Short-Termism: Does the Corporate Legal Landscape Facilitate Managerial Myopia?, 5 UCL J.L. \& JURIS. 285, 305 (2016) ("By analysing questionnaire responses of boards of directors of over 200 listed companies, research conducted [by Demirag] over 15 years ago concluded that if managers perceive the market will evaluate the company using short-term criteria, they will behave myopically."); Istemi S. Demirag, Boards of Directors' Short-term Perceptions and Evidence of Managerial Short-termism in the UK, 4 EUR. J. FIN. 195, 204 (1998) ("More than half (51.1\%) of the [boards of directors] perceived that analysts and major shareholders often exhibited a strong bias against high-risk long-term research in favour of lower-risk short-term product development."); Walker, supra note 33, at 441 (“[M]anagers might 
the problem may not be management overconfidence, but rather a persistent error of perception. Such errors could result from dysfunctional cognition, which leads managers to erroneously perceive a threat of investor short-termism. 44 Alternatively, it could be the result of the complexity of the managerial problem and bounded rationality, which together may lead a manager "to limit her search for information or consideration of the decision short of reaching a utilitymaximizing decision." 45

In either case, this is not mere quibbling. Policies that are well suited to improve the accuracy of managerial perceptions of market preferences may differ from those well suited to reduce managerial confidence to optimal levels. Where misperceptions are based on erroneous beliefs or information processing failures, for example, "presenting corrective messages in convenient and accessible formats should reduce misperceptions." 46 In contrast, to correct the overconfidence bias, "policymakers will have to set ... penalties higher, sometimes substantially so, than they would in a world of utility-maximizing actors who are not systematically overconfident." 47 The latter seems a considerably harsher strategy than the former.

believe that the market is myopic and shape their own behavior accordingly.").

44 See, e.g., Larry Cunningham, Using Principles from Cognitive Behavioral Therapy to Reduce Nervousness in Oral Argument or Moot Court, 15 NEV. L.J. 586, 594 (2015) (defining "dysfunctional cognition" as existing when the subject "erroneously believes there is a threat").

45 Korobkin \& Ulen, supra note 14, at 1077.

46 See S.I. Strong, Alternative Facts and the Post-Truth Society: Meeting the Challenge, 165 U. PA. L. REV. ONLINE 137, 138 \& n.4 (2017) (quoting Brendan Nyhan \& Jason Reifler, The Roles of Information Deficits and Identity Threat in the Prevalence of Misperceptions, (Feb. 24, 2017) (unpublished manuscript), http://www.dartmouth.edu/ nyhan/openingpolitical-mind.pdf [https://perma.cc/T36Q-HG59]).

47 Korobkin \& Ulen, supra note 14, at 1092. Korobkin and Ulen's argument is premised on the assumption that "rational choice theory advises policymakers [who wish to deter some form of conduct] to set the penalty for the undesirable conduct such that the desired fraction of the population-say, potential injurers-will calculate that the expected costs of the conduct exceed the expected benefits to them." Id. If decisionmakers 
C. The Case Studies

Barzuza and Talley offer three case studies. First, they explore Marissa Mayer's effort to remake Yahoo to compete with Google and Facebook. 48 After a four-year run in which Yahoo spent almost $\$ 3$ billion to acquire over 50 companies, Yahoo remained moribund.49 Under pressure from activist hedge fund Starboard Value, the Yahoo board abandoned Mayer's plan, sold Yahoo's core business to Verizon, and parted ways with Mayer.50

Second, Barzuza and Talley survey Tim Armstrong's efforts to revive AOL.51 Armstrong's efforts focused on a news platform called Patch.52 Although Armstrong managed to fend off an activist campaign by Starboard, he did so mainly by promising investors that Patch would be cut loose if it remained unprofitable.53 When Patch remained a failure, Armstrong was finally compelled to relinquish AOL's control of Patch. 54

Finally, Barzuza and Talley review Dan Ustian's tenure as CEO of Navistar. 55 As they tell the story, Ustian was strongly committed "to innovation and long-term growth."56 As a key

are overly confident, however, they will overestimate the odds of success and underestimate the odds of punishment. See id. ("If bank robbers believe that they are less likely to be apprehended than their peers, if absentminded drivers believe they are less likely to cause an accident than other drivers, or if some physicians believe they are less likely to be found liable for malpractice than other physicians, penalties for the undesirable behavior will have to be higher than policymakers would otherwise think necessary to achieve the desired level of deterrence.").

48 Barzuza \& Talley, supra note 12 , at 156-62.

49 See id. at 161 (noting that "the plan did not produce the growth investors and management hoped for").

50 See id. (summarizing the Yahoo board's response to Starboard's intervention).

51 See id. at 162-66 (describing Armstrong's tenure leading AOL).

52 See id. at 163 ("Armstrong believed he had a winning card—Patch, a local news web platform[.]").

53 Id. at 163-64.

54 Id. at 164-65.

55 Id. at 167-72.

56 Id. at 167. 
example, they point to Ustian's decision to develop a new technological solution for meeting EPA pollution regulations instead of using the existing technology used by all of Navistar's competitors. 57 Ultimately, Navistar abandoned the project and resorted to the widely used technology, having spent ten years and $\$ 700$ million on the failed effort. 58 Both before and after the decision to abandon the project, Navistar was subject to significant pressure from hedge fund activists, which culminated in Ustian being fired and activist investors Carl Icahn and Mark Rachesky each receiving permission to appoint two Navistar directors.59 As Barzuza and Talley summarize the Navistar case study, "Ustian became increasingly invested in the project, so much so that he ignored mounting data and engineers' concerns, and dismissed the anemic market value that investors accorded Navistar, which to him was simply a reflection of shorttermism."60

In Barzuza and Talley's telling, each of these case studies involves an over-optimistic CEO who overestimated the likelihood of their chosen long-term project's success. 61 But how much weight should we give three case studies, two drawn from the heart of the technology sector and the third (Navistar) involving a company that was run more like an "internet incubator" than "a truck and engine company"?62 Three is a pretty small sample size, especially when all are drawn from what amounts to a single industry sector. The problem is compounded, because the technology sector long has been notoriously overoptimistic compared to more prosaic sectors. 63

57 See id. at 167-68 (describing the decision).

58 Id. at 171.

59 See id. at 171-72.

60 Id. at 172.

61 Id. at 113.

62 Id. at 167.

63 See, e.g., Mark Simon \& Susan M. Houghton, The Relationship Between Overconfidence and the Introduction of Risky Products: Evidence from a Field Study, 46 ACAD. MGMT. J. 139, 140 (2003) (linking pioneering behavior and managerial overconfidence); Donald C. Langevoort, Taking 
The utility of the case studies is open to further doubt, because they involve unusual hedge fund conduct. The bulk of shareholder activism involves intervening in takeover contests, not intervening when management overinvests in projects. 64 Per a recent report, "[o]ther ways to increase a target's share price, such as criticizing everyday performance or high costs, declined in popularity compared with previous years. With corporate debt high, there also are fewer gains to be made by pushing companies to borrow to fund share buybacks or dividends." 65 Yet, those are precisely the tactics the case studies involve, so one cannot generalize from three case studies - in which hedge funds behaved abnormally-to the much larger number of cases in which we can expect hedge funds to behave normally. The case studies thus do not tell us very much about Barzuza and Talley's proposed interventions, especially those that are intended to encourage shareholder activism. Perhaps the analysis would be different if these interventions resulted in a change in hedge fund practices, but they do not appear to target this result.

On close examination, moreover, one can spin alternative stories about each of the case studies. At Yahoo, for example, Barzuza and Talley claim that the problem was that Mayer was too wedded to her plans and that an intervention was necessary to prevent the money-losing plan from continuing. 66 But Barzuza and Talley themselves admit that other

Myths Seriously: An Essay for Lawyers, 74 CHI-Kent L. REv. 1569, 1584 (2000) (observing that tech "start-up entrepreneurs are a well-studied breed, prone toward greater over-optimism and illusions of control than the general population"). Cf. also Victor Fleischer, The Rational Exuberance of Structuring Venture Capital Start-Ups, 57 TAX L. REV. 137, 141 (2003) (referring to "the stereotypical Silicon Valley venture capitalist afflicted with rose-tinted vision" although only partially endorsing the stereotype); Alan Murray, Antitrust Isn't Obsolete in an Era of High Tech, WALL ST. J., Nov. 10, 1997, at A1 (incidentally noting the existence of "technooptimists").

64 Carol Ryan, Activist Investors and the Art of the Deal, Wall ST. J. (Jan. 23, 2020), https://www.wsj.com/articles/activist-investors-and-the-artof-the-deal-11579691335 (on file with the Columbia Business Law Review).

65 Id.

66 See Barzuza \& Talley, supra note 12 , at $161-62$. 
commentators have characterized what happened at Yahooand in their other case studies-as a triumph of shorttermism, resulting from pressure by an activist hedge fund. 67

One could fairly characterize the AOL case study, for another example, as a story about managerial incompetence rather than over-optimism. Armstrong fired AOL CFO Arthur Minson after Minson became a Patch skeptic.68 Armstrong publicly and "impulsively fired" AOL creative director Abel Lenz "during a company conference call involving around 1,000 co-workers." 69 Business Insider quoted a "source close to" Armstrong as saying it "made Armstrong sound unhinged-'schizophrenic in his thinking."70 Likewise at Navistar, "Ustian practically quarantined his office away from company engineers and dismissed employees who were vocally skeptical."71 All of which-acting impulsively and shifting the blame for failed projects onto subordinatesstrikes this observer as a classic example of toxic management. ${ }^{72}$ In turn, this observation suggests that the problem is not the choice of time horizon. After all, one suspects that toxic managers will be incompetent whether they are focused on the short term or the long term.

Returning to the AOL case study, while there is a hint of academic snobbery in Barzuza and Talley's characterization of Armstrong as "a one-time salesperson," 73 it seems plausible that the Armstrong saga is a classic example of the Peter

67 See id. at 155 ("Any of these episodes could have been described as examples of short-termist interventions in long-term investments (and indeed they were so characterized at the time).").

68 Id. at 165.

69 Id.

70 Nicholas Carlson, The Story Behind Why AOL CEO Tim Armstrong Fired an Employee in Front of 1,000 Coworkers, Bus. INSIDER (Nov. 6, 2013, 10:12 PM), https://www.businessinsider.com/tim-armstrong-patch-aol2013-10?page=1 [https://perma.cc/L8MX-TMH7].

71 Barzuza \& Talley, supra note 12 , at 115-16.

72 See Ronald E. Riggio, The 10 Habits of Highly Toxic Bosses, PsycH. TODAY (Feb. 19, 2018), https://www.psychologytoday.com/us/blog/cuttingedge-leadership/201802/the-10-habits-highly-toxic-bosses [https://perma.cc/GUH4-FC99].

73 Barzuza \& Talley, supra note 12, at 162. 
Principle 74 at work. After he took charge at AOL, Armstrong "made missteps, gaffes, and strange decisions that reminded people that he was a rookie CEO."75 Similarly, some commentators have cited Yahoo's Mayer as another illustration of the Peter Principle, with some suggesting she had already reached the level of her incompetence while still at Google. 76 Managers who have reached the level of their incompetence by definition will be incompetent whether they are overly optimistic 77 or not and whether they focus on the short term or the long term.

In sum, the case studies prove unpersuasive. We have a small number of cases drawn from the same famously overconfident milieu. More importantly, what we have in each case arguably is not so much a story about managerial hyperopia but one of managerial incompetence. As we shall see in the Parts that follow, this possibility matters when it comes to drawing policy implications from Barzuza and Talley's work.

\section{THE JUDICIAL ROLE}

According to Barzuza and Talley, "Delaware courts have recently begun to float concerns about short-termism and its implications for fiduciary conduct."78 In particular, Barzuza and Talley express concern that decisions such as Trados 79

74 See Laurence J. Peter, The Peter Principle 25 (1969) (“[I]n a hierarchy every employee tends to rise to his level of incompetence.").

75 Carlson, supra note 70.

76 See, e.g., Tim Knight, Two Blondes, Two Fates, ZeroHedge (Apr. 28, 2017, 10:28 PM), https://www.zerohedge.com/news/2017-04-28/two-blondestwo-fates [https://perma.cc/H7F7-L8HN] ("In a perfect illustration of the Peter Principle, Mayer had risen to her own level of incompetence at Google, and she started getting sidelined.").

77 Obviously, overconfidence and incompetence sometimes overlap; "overconfidence in one's skills is often a hallmark of the incompetent." Ruth Vance \& Susan Stuart, Of Moby Dick and Tartar Sauce: The Academically Underprepared Law Student and the Curse of Overconfidence, 53 DuQ. L. REV. 133, 144 (2015).

78 Barzuza \& Talley, supra note 12 , at 185.

79 In re Trados Inc. S'holder Litig., 73 A.3d 17 (Del. Ch. 2013). 
"have begun to modify the framework for assessing directors' fiduciary duties, requiring that directors 'manage for the longterm' on behalf of 'permanent capital' (often favoring common shareholders over preferred shareholders holding redemption or exit rights)." 80 Although Barzuza and Talley acknowledge that courts have not yet held myopic directors liable, they contend that "it is likely a matter of time before the full measure of liability exposure begins to emerge." 81 Pointing to their analysis of managerial over-optimism, Barzuza and Talley "advise Delaware courts to continue to utilize caution in applying long-termist fiduciary duties-or at least to work through how long-term and short-term biases interact with one another." 82

I want to differ with Barzuza and Talley on three points. First, I believe Barzuza and Talley overstate the risk of judicial intervention. Second, they fail adequately to distinguish between directors and managers, even though that distinction is central to the application of Delaware law. Third, I believe their case studies and behavioral analysis imply that judges should retain the deference to director decisionmaking inherent in doctrines like the business judgment rule.

\section{A. Is it Really Just a "Matter of Time"?}

Delaware Supreme Court precedent makes clear that "the question of 'long-term' versus 'short-term' values is largely irrelevant because directors, generally, are obliged to chart a course for a corporation which is in its best interests without regard to a fixed investment horizon." 83 Trados and its ilk do not appear to mark a major shift in that longstanding principle. Instead, "the predominate [sic] view today" remains that "directors have discretion in taking corporate action,

80 Barzuza \& Talley, supra note 12, at 185.

81 Id. at 186.

82 Id.

83 Paramount Commc'ns, Inc. v. Time Inc., 571 A.2d 1140, 1150 (Del. 1989). 
including setting a time horizon that would maximize the value of the corporation as a whole." 84

Indeed, Vice Chancellor Laster, who authored the Trados opinion, has acknowledged that management need not always focus on long-term projects: "A fiduciary might readily determine that a near-term sale or other shorter-horizon initiative, such as declaring a dividend, is value-maximizing even when judged against the long-term." 85 More generally, in a law review article discussing the fiduciary duties of directors faced with an activist shareholder, Laster explained that Delaware law creates "a relatively strong standard of conduct combined with relatively weak litigation enforcement mechanisms in which the strong standard of conduct is dominated by deferential standards of review." 86 As a result, "[t]he likelihood of a lawsuit that can overcome the business judgment rule is low." 87

\section{B. Directors Direct, and that Matters}

Barzuza and Talley's analysis-both the behavioral economics portion and the case studies-focus on managers. But courts rarely concern themselves with managers. Instead, most court decisions dealing with fiduciary duties in the corporate setting are concerned with directors. ${ }^{88}$ Likewise, corporate statutes make directors-rather than officersresponsible for the management of the firm. 89 Responsibility

84 Shachar Nir, One Duty to All: The Fiduciary Duty of Impartiality and Stockholders' Conflict of Interest, 16 HASTINGs Bus. L.J. 1, 31 (2020).

85 Frederick Hsu Living Tr. v. ODN Holding Corp., No. 12108-VCL, 2017 WL 1437308, at *19 (Del. Ch. Apr. 14, 2017), as corrected, (Apr. 24, 2017).

86 J. Travis Laster, Fiduciary Duties in Activist Situations, 13 VA. L. \& Bus. REV. 75, 99 (2019).

87 Id.

88 Cf. Martin Petrin, Corporate Management in the Age of AI, 2019 Colum. Bus. L. REV. 965, 1012 (noting that "fiduciary duty lawsuits against officers have been rare").

89 See, e.g., Del. Code ANN. tit. 8, § 141(a) (2020) ("The business and affairs of every corporation organized under this chapter shall be managed by or under the direction of a board of directors[.]"). 
for monitoring and constraining overconfident managers thus is a task the law traditionally assigns to boards of directors rather than judges, and there are good reasons to think this assignment remains optimal We know, for example, that merely warning decisionmakers to be careful to avoid overconfidence does not appear to be sufficient to overcome that bias. 90 Instead, one must induce decisionmakers to think actively about potential weaknesses in their plans and ask them to anticipate objections. 91 We also know that one can minimize the impact of the overconfidence bias by soliciting so-called "outside views"-statistical analyses and aggregate data about outcomes from similar projects carried out by others.92 Finally, as Barzuza and Talley observe, a key constraint on the overconfidence bias is clear and prompt feedback. 93

All of these approaches are better suited for a board than for outsiders such as judges (or, pertinently to the next Part, shareholders). Ensuring that managers get feedback from outside perspectives is inherent in the structure of the modern public corporation board of directors. Stock exchange listing standards mandate that public companies have at least a majority of independent directors. 94 In practice, larger public companies commonly have one or, at most, two inside directors, with the rest being independent.95 One of the

90 Russell Korobkin, Psychological Impediments to Mediation Success: Theory and Practice, 21 OHIO ST. J. ON DisP. RESOL. 281, 294-95 (2006).

$91 C f$. $i d$. at 295 (discussing this strategy in the mediation setting).

92 Barzuza \& Talley, supra note 12 , at 147-48.

93 See id. at 151 ("Several researchers have found that the mere expectation of clear and immediate feedback dampens undue optimism in making predictions.").

94 See Roberta Romano, The Sarbanes-Oxley Act and the Making of Quack Corporate Governance, 114 YALE L.J. 1521, 1575 n.156 (2005) (noting that the stock exchanges have "amended their listing requirements to require listed companies to have a majority of independent directors on their boards and completely independent nominating and compensation committees").

95 See Jeffrey N. Gordon, The Rise of Independent Directors in the United States, 1950-2005: Of Shareholder Value and Stock Market Prices, 59 STAN. L. REV. 1465, 1476 (2007) ("Large public firms have moved to a 
principal justifications for this trend is that independent directors bring outside perspectives to bear.96 Although insiders could hire outside consultants to provide such perspectives, insiders only can "be forced both to expose their biases and to take dissonant viewpoints seriously" if they cede "formal power to a more objective group of outsiders ([by] making them directors)."97

\section{The Judges Are Not Business Experts}

Some readers might concede that boards of directors ought to be the front-line defense against managerial overconfidence but still argue that, because boards often fail adequately to monitor management, judicial review might be a useful backup mechanism for policing managerial hyperopia. Barzuza and Talley come closest to doing so in connection with judicial review of target company resistance to unsolicited takeover bids. Although they acknowledge that the law of corporate takeovers is unlikely to change dramatically, they argue that "[their] analysis suggests the distinct cost of placing too much discretion in the hands of overconfident managers; at the very least, the potential danger of longtermism should factor into the analysis." 98

What I take away from their article, however, is that judicial deference to board decisions remains the optimal rule in both operational and takeover settings because of the challenges involved in judicial assessment of behavioral

pattern of one, perhaps two, inside directors and an increasing number of independent directors.").

96 See Donald C. Langevoort, The Human Nature of Corporate Boards: Law, Norms, and the Unintended Consequences of Independence and Accountability, 89 GEO. L.J. 797, 797 (2001) ("Absent some sort of crisis, outside members see their value largely in terms of constructive advice, giving insiders the benefit of an expert external perspective on the company's uncertain world.”).

97 Id. at 803.

98 The quoted analysis appears in a discussion of judicial supervision of managerial biases. See Barzuza \& Talley, supra note 12, at 189. 
biases.99 Over a century ago, the Michigan Supreme Court famously opined that "judges are not business experts."100 Although that aphorism cannot be a complete explanation for the business judgment rule, it is an important part of the justification.101 As Eric Posner usefully explained, many judges are "radically incompetent"102 when it comes to business issues:

[C]ourts have trouble understanding the simplest of business relationships. This is not surprising. Judges must be generalists, but they usually have narrow backgrounds in a particular field of the law. Moreover, they often owe their positions to political connections, not to merit. Their frequent failure to understand transactions is well-documented. One survey of cases involving consumer credit, for example, showed that the judges did not even understand the concept of present value .... Skepticism about the quality of judicial decisionmaking is reflected in many legal doctrines, including the business judgment rule in corporate law, which restrains courts from secondguessing managers and directors[.] ${ }^{103}$

99 To be sure, in the takeover setting, the board of directors' inherent conflict of interest justifies some preliminary analysis of the board's motives before a court defers to their decision. See Stephen M. Bainbridge, Unocal at 20: Director Primacy in Corporate Takeovers, 31 DEL. J. CoRP. L. 769, 862 (2006) ("[I]f [the board acts properly], respect for authority values will require the court to defer to the board's substantive decisions. The board has legitimate authority in the takeover context, just as it has in proxy contests and a host of other decisions that nominally appear to belong to the shareholders.").

100 Dodge v. Ford Motor Co., 170 N.W. 668, 684 (Mich. 1919).

101 See Stephen M. Bainbridge, The Business Judgment Rule as Abstention Doctrine, 57 VAND. L. REV. 83, 117-24 (2004) (explaining how the judicial lack of business expertise relates to the business judgment rule).

102 Eric A. Posner, A Theory of Contract Law Under Conditions of Radical Judicial Error, 94 Nw. U. L. REV. 749, 754 (2000).

$103 I d$. at 758 (footnote omitted). On the other hand, this critique is less relevant to the members of the Delaware courts, who have substantial opportunity and incentive to specialize in business issues. See Bainbridge, supra note 101, at 120-21 (discussing Delaware courts). 
With that background in mind, consider Barzuza and Talley's case studies. As they themselves admit, other commentators have spun those case studies as examples of short-termism on the part of the intervening hedge funds. 104 In addition, as I have argued, their case studies just as easily can be characterized as stories about managerial incompetence without regard to time horizon issues. 105

In sum, even with the benefit of hindsight, it often will be difficult even for business experts to tell whether management erred in either a short- or long-term direction or to distinguish such a time horizon error from other forms of incompetence. So why should we expect judges, who are by their own admission not business experts, to make the distinction? The lesson to be drawn is that judges should (absent a conflict of interest) leave the task of policing managerial time horizon biases to the board of directors.

\section{ACTIVIST SHAREHOLDERS TO THE RESCUE?}

While Barzuza and Talley are appropriately modest—one might even say reticent-in making recommendations for changes in the judicial role, they are somewhat more interventionist when it comes to the role of activist shareholders. They defend activists from various charges. They cite studies concluding, for example, "that while activism reduces investment in $R \& D$ and [capital expenditures] in general, it also leads to increased returns on assets, and higher output measures (such as more patent registrations and citations)."106 They posit that hedge fund pressure on companies to pay dividends and effect stock repurchases limits "the most problematic types of long-term investments." 107 They contend that directors nominated by activist investors contribute to a "long-term improvement in operating performance-during the five years following

104 See supra text accompanying note 67.

105 See supra text accompanying notes 68-77 (discussing case studies).

106 Barzuza \& Talley, supra note 12, 176-77.

107 Id. at 178 (emphasis omitted). 
activism, returns on assets increased by more than $2 \%$ on average[.]"108

This leads Barzuza and Talley to cast doubt on proposed legal changes that would curb hedge fund activism. They are skeptical of proposed amendments to the Securities Exchange Act $\S 13(\mathrm{~d})$ disclosure regime 109 that would require persons who acquire five percent or more of a class of a company's equity securities to file the Schedule 13D disclosure statement sooner than current law requires.110 They are likewise skeptical of proposals that would require Schedule $13 \mathrm{D}$ to contain greater information. 111

In contrast, I support these changes and more besides. I have elsewhere argued, for example, that Rule 14a-8 (the shareholder proposal rule) should be amended to allow companies to opt out of it.112 I have further argued for the expansion and revitalization of the existing provision that allows companies to exclude proposals relating to matters of ordinary business. ${ }^{113}$ I support requiring activists "to provide greater disclosures with respect to their motivations, goals, economic interests, and holdings of the issuer's securities (including derivative positions), so that their fellow shareholders can assess whether the activist's goals are consistent with the interests of all shareholders."114 Finally, I support imposing a longer holding period on investors before they can make use of Rule 14a-8.115

108 Id. at 180

109 For a detailed discussion of that regime, see STEPHEN M. BAinbridge, Corporate LAW 432-37 (4th ed. 2020).

110 See Barzuza \& Talley, supra note 12 , at 182-83.

111 Id.

112 Stephen M. Bainbridge, Preserving Director Primacy by Managing Shareholder Interventions, in RESEARCH HANDBOOK ON SHAREHOLDER Power 231, 246 (Jennifer G. Hill \& Randall S. Thomas eds., 2015)

113 Id.

$114 I d$.

115 Id. In September 2020, the SEC amended Rule $14 \mathrm{a}-8$ to raise both the threshold at which a shareholder becomes eligible to submit a proposal under the rule and the holding period the shareholder must satisfy to do so. Under the prior version of the rule, a shareholder-proponent must have owned at least one percent or $\$ 2,000$ (whichever is less) of the issuer's voting 
Of particular relevance to Barzuza and Talley's apparent support for allowing activists to nominate directors, 116 I support regulating-and perhaps banning-the golden leashes 117 by which activists maintain control over such directors 118:

The recent trend toward such payments raises serious conflicts of interest, as the hedge fund's nominees likely will be loyal to the fund rather than the issuer. In particular, such directors have financial incentives

securities for at least one year prior to the date on which the proposal is submitted. Procedural Requirements and Resubmission Thresholds Under Exchange Act Rule 14a-8, 85 Fed. Reg. 70,240, 70,241 (Sept. 23, 2020) (to be codified at 17 C.F.R. pt. 240). As amended, the rule now requires that a proponent have

continuously held at least: $\$ 2,000$ of the company's securities entitled to vote on the proposal for at least three years; $\$ 15,000$ of the company's securities entitled to vote on the proposal for at least two years; or $\$ 25,000$ of the company's securities entitled to vote on the proposal for at least one year.

Id. (bullet points omitted).

116 See Barzuza \& Talley, supra note 12, at 186 (expressing concern that "[t]he emerging Delaware approach ... could expose directors that were nominated by activist hedge funds to a nontrivial risk of liability").

117 Golden-leash arrangements generally are defined as agreements or arrangements made by activist shareholders to pay a director or director nominee in connection with his or her service on, or candidacy for, a company's board of directors, usually in connection with a proxy fight. In a typical arrangement, a director or nominee is entitled to receive certain compensation directly from the relevant activist shareholder if the company's stock price performs in a certain manner over a specific time period.

Brian R. Rosenau, NASDAQ Adopts Rule Requiring Disclosure of GoldenLeash Arrangements, Bus. L. TodAY, Sept. 2016, at 1.

118 See Bainbridge, supra note 112, at 246 ("The proxy rules also should be amended to prevent hedge funds from compensating those members of an issuer's board of directors that were nominated by the fund."). 
to acquiesce in —or even assist—private rent seeking by their fund sponsor. 119

As Greg Shill has pointed out, Trados and the other similar recent cases that Barzuza and Talley characterize as involving judicial concern with short-termism 120 are really about "conflicts between the duties [directors nominated by activist investors] owe their nominating funds and the companies on whose boards they serve." 121 As Professor John Coffee has observed, those conflicts are real and serious. 122 Golden-leash arrangements "can give rise to a conflict of interest that induces a director to subordinate his or her own judgment to that of the institution paying the director." 123 Such arrangements "create the wrong incentives, fragment the board, and imply a shift towards both the short-term and higher risk." 124

The implication I draw from Barzuza and Talley's analysis thus is that it strengthens the case for director primacy-i.e., protecting the board of directors from interventions by shareholders. Although Delaware law offers occasional platitudes purportedly elevating shareholder voting to pride of place, 125 Delaware law in fact remains board-centric. ${ }^{126} \mathrm{As}$

119 Id. For a comprehensive analysis of golden leashes, see generally Matthew D. Cain et al., How Corporate Governance Is Made: The Case of the Golden Leash, 164 U. PA. L. REV. 649 (2016).

120 See supra notes 78-82 and accompanying text (discussing Barzuza and Talley's concern with Trados and its ilk).

121 Gregory H. Shill, The Golden Leash and the Fiduciary Duty of Loyalty, 64 UCLA L. REV. 1246, 1286 (2017).

122 John C. Coffee, Jr., Shareholder Activism and Ethics: Are Shareholder Bonuses Incentives or Bribes?, The CLS BluE SKY BlOG (Apr. 29, 2013), http://clsbluesky.law.columbia.edu/2013/04/29/shareholderactivism-and-ethics-are-shareholder-bonuses-incentives-or-bribes/ [https://perma.cc/6N43-G68D].

$123 \mathrm{Id}$.

$124 I d$.

125 See, e.g., Blasius Indus. v. Atlas Corp., 564 A.2d 651, 659 (Del. Ch. 1988) ("The shareholder franchise is the ideological underpinning upon which the legitimacy of directorial power rests.").

126 See Gorman v. Salamone, No. 10183-VCN, 2015 WL 4719681, at *4 n.18 (Del. Ch. July 31, 2015) (“[A] Delaware corporation is a board-centric 
I have argued elsewhere, Delaware law thus rests not on a model of shareholder primacy but rather on one of director primacy.127 Limits on shareholder power follow directly from the director primacy model128:

Given the collective action problems inherent to such a large number of potential decisionmakers, the differing interests of shareholders, and their varying levels of knowledge about the firm, it is "cheaper and more efficient to transmit all the pieces of information once to a central place" and to have the central office "make the collective decision and transmit it rather than retransmit all the information on which the decision is based." Shareholders therefore will prefer to irrevocably delegate decisionmaking authority to some smaller group. As we have seen, that group is the board of directors.

Strong limits on shareholder control are essential if that optimal allocation of decisionmaking authority is to be protected. Any meaningful degree of shareholder control necessarily requires that shareholders review management decisions, and step in when management performance falters to effect a change in policy or personnel. Giving shareholders this power of review differs little from giving them the power to make management decisions in the first place. Even though shareholders probably would not micromanage portfolio corporations, vesting them

entity.”); In re CNX Gas Corp. S'holders Litig., No. 5377-VCL, 2010 WL 2705147 , at *10 (Del. Ch. July 5, 2010) ("Delaware law would seem to call for a consistently board-centric approach.”); see also J. Travis Laster \& John Mark Zeberkiewicz, The Rights and Duties of Blockholder Directors, 70 Bus. LAW. 33, 35 (2014) ("Delaware corporate law embraces a 'board-centric' model of governance.").

127 See, e.g., Stephen M. Bainbridge, Star Lopez \& Benjamin Oklan, The Convergence of Good Faith and Oversight, 55 UCLA L. REv. 559, 567 (2008) ("Delaware case law consistently indicates a regime of director primacy."). Delaware courts have concurred. See, e.g., In re CNX Gas Corp. S'holders Litig., at *15 ("[D]irector primacy remains the centerpiece of Delaware law, even when a controlling stockholder is present.").

128 See Stephen M. Bainbridge, The Case for Limited Shareholder Voting Rights, 53 UCLA L. REv. 601, 616-19 (2006) (discussing those limits). 
with the power to review board decisions inevitably shifts some portion of the board's authority to them. As Arrow explained:

Clearly, a sufficiently strict and continuous organ of [accountability] can easily amount to a denial of authority. If every decision of $\mathrm{A}$ is to be reviewed by $\mathrm{B}$, then all we have really is a shift in the locus of authority from A to B and hence no solution to the original problem.

This remains true even if only major decisions of $\mathrm{A}$ are reviewed by B. The separation of ownership and control mandated by U.S. corporate law effects thus has a strong efficiency justification. 129

Turning from the general case against shareholder empowerment to the specifics of hedge fund activism, we "must consider whether the incentives created for institutional investors - the 'empowered shareholders' of today-tilt toward the short term or may be otherwise biased."130 Barzuza and Talley concede that-like all humans-hedge fund managers are subject to their own set of biases, but suggest that fund manager biases towards the short-term are useful because they counteract managers' hyperopia.131 They argue that hedge fund short-termism "may represent an efficient counter-ballast against at least certain forms of long-termist overinvestment." 132

129 Stephen M. Bainbridge, An Abridged Case for Director Primacy, 62 UCLA L. REv. Discourse 69, 70 (2014) (footnotes omitted) (quoting Kenneth J. Arrow, The Limits of Organization 68, 78 (1974)).

130 Usha Rodrigues, Corporate Governance in an Age of Separation of Ownership from Ownership, 95 MINN. L. REV. 1822, 1828 (2011). In addition, recall that hedge fund activism aimed at management's long-term bias is rare. See supra note 64 and accompanying text.

131 See Barzuza \& Talley, supra note 12, at 174 ("[T] long- and short-term biases probably does not always result in perfectly optimal outcomes, but by plausibly interacting in this way, short-term bias and long-term bias will tend to mitigate one another's greatest shortcomings.").

132 Id. at 117. 
Even if we assume that hedge fund managers tend to be biased towards the short-term, which seems likely, 133 there are a number of reasons to be skeptical of Barzuza and Talley's argument. First, as Barzuza and Talley concede, management can sometimes be biased towards short-term goals. 134 In cases where management is engaged in undesirable short-termism, hedge fund activism of the sort Barzuza and Talley wish to encourage would simply compound the problem by adding an additional source of pressure for managers to prefer the short term.

Second, Barzuza and Talley present no evidence that hedge fund activism motivated by managerial long-term bias is sufficiently pervasive to act as a meaningful constraint. To the contrary, the fact that hedge fund activism rarely takes forms that would address managerial short-term biases 135 suggests that it is not a meaningful constraint on those biases.

Third, even if hedge fund activism counterbalances management short-termism, it may be an undesirable way of achieving that goal, because the interests of hedge funds may conflict not only with those of managers but also with those of other shareholders. Investor time horizons vary widely from short- to long-term. ${ }^{136}$ In turn, such variations can lead to wide divergence in preferences. 137 As Usha Rodrigues thus observes, assuming "shareholders have different interests, most notably divergent investment time horizons, then simply

133 See Bowdren, supra note 43, at 299 (arguing that shareholder activism tends to be focused on the short term).

134 See Barzuza \& Talley, supra note 12, at 120 (acknowledging shortterm pressures and biases on the part of corporate managers).

135 See Ryan, supra note 64 (discussing forms of hedge fund activism).

136 See Ugur Lel \& Mete Tepe, Investor Horizon and Managerial ShortTermism 1-2 (Mar. 11, 2019) (unpublished manuscript), https://papers.ssrn.com/sol3/papers.cfm?abstract_id=3209865 (on file with the Columbia Business Law Review) (arguing that "investment horizon is a distinguishing feature of shareholders, and it can affect optimal corporate policies and firm valuation in markets with incomplete information").

137 See id. at 2 ("For example, short-term shareholders may desire R\&D expenditures to be reduced, which creates a conflict of interest between long-term and short-term shareholders." (citation omitted)). 
empowering [activist] investors risks advantaging one group of shareholders to the detriment of the rest."138

Another reason to believe that hedge fund activism is not a desirable way of addressing management's long-term bias is that managerial biases are not the only biases that we must take into account:

Corporate managers are not the only ones whose decisions and actions may be influenced by the overconfidence bias. Investors also can be overconfident in their abilities to assess risks and to make wise investment decisions. Most investors overrate their stock-picking abilities and believe their investment skills are above average. Studies have shown that investors consistently overestimate both the future performance and the past performance of their investments. The illusion of control causes investors to believe that positive investment outcomes are due to investors' own skills and superior strategy, rather than good luck. 139

Once we introduce these multiple competing and interacting biases, the probability that managerial and hedge fund manager biases will cancel each other out becomes much smaller.

In addition to the biases identified by behavioral economics, monetary incentives can skew hedge fund decisionmaking. In particular, hedge fund managers and their investors have an asymmetric contract, pursuant to which the manager gets a huge chunk of gains when the fund has positive results but has little downside exposure. 140 Presumably, this is likely to induce hedge fund managers to prefer more risk than retail or other institutional investors.

138 Rodrigues, supra note 130, at 1829 (footnote omitted).

139 Ripken, supra note 28, at 960-61 (footnotes omitted).

140 See Houman B. Shadab, Hedge Fund Governance, 19 STAN. J.L. Bus. \& FIN. 141, 166 (2013) ("Hedge fund managers may have incentives to take on greater risk after obtaining investor capital because of the asymmetric payoff structure resulting from their performance-based compensation arrangement: the manager shares in the profits of a fund with investors but not in fund losses."). 
There is good reason to doubt the efficacy of hedge fund managers as a constraint on managerial hyperopia even if we set aside biases and incentives. As for the debate over dual class stock, Barzuza and Talley note that outsiders have difficulty unpacking "the motivations of a founder who embraces a dual class structure; it may be due to overconfidence (and thus value-eroding), but it could just as easily be due to a founder's genuine desire to protect a project that is inherently difficult for outsiders to assess." 141 Why should that difficulty be limited to unpacking the motivations of a founder with respect to the firm's capital structure? Why should not the same be true of the motivations of a more seasoned company's CEO with respect to corporate plans generally? Indeed, just as we saw with respect to judges in the preceding Part, "[i]t is difficult for shareholders to deduce whether a company is making sound long-term investments, which may lead to short-term losses, or if short-term losses are caused by managerial incompetence." 142

Speaking of incompetence, managers are not the only ones whose competence can be called into question. In 2018, for example, activist hedge funds "delivered returns of minus $10 \%$ to investors in their funds, according to Hedge Fund Research's Activist Index .... Returns recovered to 18\% in 2019 , but clients may still be disappointed, given the $31.5 \%$ total returns on offer from the S\&P 500 index" in 2019.143 Investors generally might be better off disempowering activists and investing in S\&P 500 index funds.

\section{CONCLUSION}

There is much to admire in Barzuza and Talley's article. Even though I have offered a few quibbles, I generally admire their compelling story that managerial hyperopia can be just as concerning as managerial myopia. I have passed over in silence much of their discussion of that story, as the implications they draw largely are well taken.

141 Barzuza \& Talley, supra note 12, at 184.

142 Bowdren, supra note 43, at 292.

143 Ryan, supra note 64. 
Where I part company with them is in my emphasis on director primacy. The responsibility for policing managerial hyperopia (or myopia, for that matter) should be assigned to the board of directors. Contrary to those who would suggest that judges, shareholders, or both would make a useful backstop to the board, I contend that someone must have final authority. If we vest the power to review board decision in either judges or shareholders, we have effectively shifted the locus of corporate decisionmaking power from the board to the shareholders or the judges:

[As Nobel laureate economist Kenneth] Arrow observed, the power to review is the power to decide. At some point, authority and accountability cannot be reconciled. One cannot have more of one without having less of the other. Once we transfer the power to review board decisions to shareholders [or judges], we have planted the seeds of the destruction of the system of centralized decisionmaking on which efficient corporate governance rests. 144

Tolerating a certain amount of managerial hyperopia is thus a necessary cost of having an efficient board-centric system of corporate governance.

144 Stephen M. Bainbridge, Director Primacy in Corporate Takeovers: Preliminary Reflections, 55 STAN. L. REV. 791, 807 n.92 (2002) (citation omitted). 